\title{
STRATEGI AKTIF UNTUK MENINGKATKAN PRESTASI BELAJAR PENDIDIKAN AGAMA ISLAM
}

\author{
Siti Rozinah \\ Prodi Pendidikan Agama Islam, Fakultas Agama Islam, Universitas Nahdlatul Ulama \\ Indonesia \\ E-mail: sitirozinah@unusia.ac.id
}

\begin{abstract}
Article Information
Informasi Artikel

Naskah diterima: 20

Maret 2018

Naskah direvisi: 15 Juni 2018

Naskah disetujui: $10 \mathrm{Juli}$

Maret

Naskah dipublish: 12 Oktober 2018
\end{abstract}

\section{Kata Kunci Pendidikan Agama Islam, Prestasi Belajar, Strategy}

\begin{abstract}
Abstak
Pendidikan merupakan salah satu tolak ukur bagi kemajuan dan kualitas kehidupan suatu bangsa maka tak heran apabila upaya dalam peningkatan mutu serta pengembangannya banyak dilakukan. Peningkatan mutu pendidikan merupakan serangkaian usaha pemerintah yang sedang digalakkan pada saat ini. Hal ini merupakan pengejawantahan dari tujuan kemerdekaan Negara Republik Indonesia. Di mana tercantum dalam pembukaan UUD 945 pada alinea ke 4, disebutkan bahwa salah satu tujuan kemerdekaan Indonesia adalah mewujudkan kesejahteraan umum dan mencerdaskan kehidupan bangsa. Upaya meningkatkan kualitas pendidikan terus menerus dilakukan baik secara konvensional maupun inovatif. Hal itu lebih terfokus lagi setelah diamanatkan bahwa tujuan pendidikan nasional adalah untuk meningkatkan mutu pendidikan pada setiap jenis dan jenjang pendidikan.
\end{abstract}

\section{PENDAHULUAN}

Pendidikan agama Islam merupakan suatu usaha untuk membina dan mengasuh peserta didik agar senantiasa dapat memahami ajaran Islam secara menyeluruh. Lalu menghayati tujuannya, dan pada akhirnya dapat mengamalkan serta menjadikan Islam sebagai pegangan hidup. Hal ini sebagaimana diungkapkan oleh Ahmad Marimba yang mengartikan pendidikan Islam sebagai bimbingan jasmani dan rohani berdasarkan hukum- hukum agama Islam menuju kepada terbentuknya kepribadian utama menurut ukuran-ukuran Islam. Sedangkan tujuan pendidikan agama Islam secara umum ialah untuk meningkatkan keimanan, pemahaman, penghayatan, dan pengalaman peserta didik tentang agama Islam, sehingga menjadi muslim yang beriman dan bertakwa 
kepada Allah SWT ${ }^{1}$. serta berakhlak mulia dalam kehidupan pribadi, bermasyarakat, berbangsa dan bernegara.

Pendidikan merupakan salah satu tolak ukur bagi kemajuan dan kualitas kehidupan suatu bangsa maka tak heran apabila upaya dalam peningkatan mutu serta pengembangannya banyak dilakukan. Peningkatan mutu pendidikan merupakan serangkaian usaha pemerintah yang sedang digalakkan pada saat ini. Hal ini merupakan pengejawantahan dari tujuan kemerdekaan Negara Republik Indonesia. Di mana tercantum dalam pembukaan UUD 945 pada alinea ke 4, disebutkan bahwa salah satu tujuan kemerdekaan Indonesia adalah mewujudkan kesejahteraan umum dan mencerdaskan kehidupan bangsa. Upaya meningkatkan kualitas pendidikan terus menerus dilakukan baik secara konvensional maupun inovatif. Hal itu lebih terfokus lagi setelah diamanatkan bahwa tujuan pendidikan nasional adalah untuk meningkatkan mutu pendidikan pada setiap jenis dan jenjang pendidikan.

Mengingat peran pendidikan yang sangat penting maka masalah-masalah mengenai pendidikan harus benar-benar mendapat perhatian dari semua pihak, khususnya perhatian dari para pakar pendidikan. Masalah pendidikan ini adalah masalah yang cukup kompleks di mana banyak faktor yang sangat mempengaruhi terhadap jalannya proses pendidikan yang pada akhirnya menentukan hasil dari pendidikan itu sendiri. Salah satu faktor yang berpengaruh besar terhadap jalannya proses pendidikan ialah keterampilan guru dalam berkomunikasi dan menyampaikan materi pembelajaran kepada peserta didik. Kemampuan guru dalam menguasai bermacam-macam strategi pembelajaran yang sesuai dengan karakteristik materi dan keadaan siswa akan sangat menentukan hasil dari kegiatan belajar mengajar.

Di sinilah guru sebagai pendidik memiliki peran yang sangat besar, di samping sebagai fasilitator dalam kegiatan belajar, guru juga berperan sebagai pembimbing untuk mengarahkan peserta didiknya sehingga menjadi manusia yang mempunyai pengetahuan luas baik pengetahuan agama, kecerdasan, kecakapan hidup, keterampilan, dan lain sebagainya. Oleh karena itu, guru harus mengetahui bagaimana situasi dan kondisi untuk menyampaikan materi kepada peserta didik. Bagaimana cara

\footnotetext{
${ }^{1}$ Marimba, Ahmad. Filsafat Pendidikan Islam, (Bandung: PT. Al-Ma'arif, 1984), h. 23 Vol. 10, No. 2 , Oktober 2019 ISSN: 1978 - 1768
} 
atau pendekatan yang digunakan dalam kegiatan belajar siswa. Bagaimana mengorganisasikan dan mengelola isi pembelajaran. Dan seberapa jauh tingkat efektivitas dari usaha-usaha yang dilakukan untuk menimbulkan daya tarik dan motivasi bagi peserta didik. Hal inilah yang menjadi alasan mengapa strategi pembelajaran sangat diperlukan dalam proses pendidikan.

\section{KAJIAN TEORI}

\section{Pengertian Pendidikan Agama Islam}

Pendidikan berasal dari kata "didik", kata ini mendapat awalan me sehingga menjadi "mendidik", artinya memelihara dan memberi latihan (ajaran, pimpinan) mengenai akhlak dan kecerdasan pikiran. Sedangkan pengertian pendidikan adalah proses pengubahan sikap dan tata laku seseorang atau kelompok orang dalam usaha mendewasakan manusia melalui upaya pengajaran dan pelatihan ${ }^{2}$.

Sedangkan menurut istilah, ada beberapa pengertian pendidikan yang diungkapkan oleh para ahli, diantaranya yaitu:

- Menurut Amir Daien Indrakusuma pendidikan adalah usaha sadar yang teratur dan sistematis, yang dilakukan oleh orang-orang yang diserahi tanggung jawab untuk mempengaruhi anak agar mempunyai sifat dan tabiat sesuai dengan cita-cita pendidikan ${ }^{3}$.

- Menurut Moh. Amin pendidikan adalah suatu usaha sadar dan teratur sistematis, yang dilakukan oleh orang-orang yang bertanggung jawab, untuk mempengaruhi anak agar mempunyai sifat dan tabiat sesuai dengan cita-cita pendidikan. Dengan kata lain pendidikan adalah bantuan yang diberikan dengan sengaja kepada anak, dalam pertumbuhan jasmani dan rohani untuk mencapai tingkat dewasa.

- Dalam Undang-Undang Sistem Pendidikan Nasional No. 20 tahun 2003 dijelaskan bahwa pendidikan adalah usaha sadar dan terencana untuk mewujudkan suasana belajar dan proses pembelajaran agar peserta didik secara aktif mampu mengembangkan segala potensinya berupa kekuatan spiritual keagamaan, pengendalian diri, kepribadian,

\footnotetext{
${ }^{2}$ Tim Penyusun Kamus Pusat Pembinaan dan Pengembangan Bahasa, Kamus Besar Bahasa Indonesia (Jakarta: Balai Pustaka, 1990), h. 204

${ }^{3}$ Indrakusuma, Amir. Pengantar Ilmu Pendidikan Sebuah Tinjauan Filosifis (Surabaya: PT Usaha Nasional, 1973), h. 27
} 
kecerdasan, akhlak mulia, serta keterampilan yang diperlukan dirinya, masyarakat, bangsa dan negara ${ }^{4}$.

Adapun beberapa pengertian pendidikan agama Islam menurut para ahli adalah sebagai berikut:

1. Muhaimin menjelaskan bahwa pendidikan agama Islam adalah usaha sadar untuk menyiapkan siswa dalam meyakini, memahami, menghayati, dan mengamalkan agama Islam melalui kegiatan bimbingan pengajaran dan latihan dengan memperhatikan tuntutan untuk menghormati agama lain dalam hubungan kerukunan antar umat beragama dalam masyarakat untuk mewujudkan persatuan nasional.

2. Menurut Zakiyah Darajat sebagaimana yang dikutip oleh Abdul Majid menegaskan bahwa pendidikan agama Islam adalah suatu usaha untuk membina dan mengasuh peserta didik agar senantiasa dapat memahami ajaran Islam secara menyeluruh. Lalu menghayati tujuan yang pada akhirnya dapat mengamalkan serta menjadikan Islam sebagai pandangan hidup.

Dari pengertian di atas dapat disimpulkan bahwa pendidikan agama Islam adalah suatu usaha sadar yang dilakukan oleh seorang guru atau pendidik untuk mengarahkan dan mengembangkan diri siswa agar memahami, meyakini, menghayati dan mengamalkan ajaran Islam dalam kehidupan sehari-hari sehingga tercapai kebahagiaan di dunia dan akhirat.

Secara umum pendidikan agama Islam bertujuan untuk meningkatkan keimanan, pemahaman, penghayatan, dan pengalaman peserta didik tenteng agama Islam, sehingga menjadi muslim yang beriman dan bertakwa kepada Allah SWT. serta berakhlak mulia dalam kehidupan pribadi, bermasyarakat, berbangsa dan bernegara.

Adapun tujuan pendidikan agama Islam menurut beberapa ahli adalah sebagai berikut:

- Menurut Moh. Amin menyatakan bahwa pendidikan agama Islam mempunyai tujuan yang identik dengan tiga aspek yaitu, iman, ilmu, dan amal.

- Menurut Abdul Majid pendidikan agama Islam bertujuan untuk menumbuhkan dan meningkatkan keimanan melalui pemberian dan pemupukan pengetahuan, penghayatan, pengalaman serta pengalaman peserta didik tentang agama Islam

\footnotetext{
${ }^{4}$ Undang-Undang Sistem Pendidikan Nasional No. 20 Tentang Sistem Pendidikan Nasional (Bandung: Penerbit Citra Umbara, 2003), h. 3
} 
sehingga menjadi manusia muslim yang terus berkembang dalam hal keimanan, ketakwaannya, berbangsa dan bernegara, serta untuk dapat melanjutkan pada jenjang pendidikan yang lebih tinggi.

Dari beberapa pendapat di atas dapat dipahami bahwa tujuan pendidikan agama Islam adalah pembentukan pribadi siswa secara menyeluruh melalui latihan kejiwaan, akal pikiran, perasaan dan pancaindra, mengembangkan seluruh aspek kehidupan manusia baik spiritual, intelektual, jasmani dan rohani, sehingga mereka dapat beramal saleh sesuai dengan ajaran agama Islam.

\section{Strategi Pembelajaran Aktif}

Adapun beberapa pengertian tentang strategi pembelajaran menurut para ahli adalah sebagai berikut:

Menurut J.R. David sebagaimana yang dikutip oleh Wina Sanjaya, strategi pembelajaran merupakan sebuah cara atau sebuah perencanaan yang berisi tentang rangkaian kegiatan yang didesain untuk mencapai tujuan pendidikan tertentu ${ }^{5}$.

Adapun strategi pembelajaran aktif merupakan istilah dalam wilayah pendidikan sebagai strategi belajar mengajar yang bertujuan untuk meningkatkan mutu pendidikan, dan untuk mencapai keterlibatan siswa secara efektif dan efisien dalam belajar. Zaini Hisyam mengungkapkan, bahwa strategi belajar aktif adalah suatu strategi pembelajaran yang mengajak siswa untuk belajar secara aktif.7 Selain guru aktif dalam pembelajaran atau dalam hal mengatur kelas, peserta didik juga mengikuti belajar dengan aktif. Dengan ini mereka secara aktif menggunakan otak, baik untuk menemukan ide pokok dari materi, memecahkan persoalan atau mengaplikasikan apa yang baru mereka pelajari ke dalam satu persoalan yang ada dalam kehidupan nyata.

Dari uraian di atas, maka dapat ditarik kesimpulan bahwa yang dimaksud dengan strategi pembelajaran aktif adalah suatu strategi pembelajaran yang mengajak peserta didik agar ikut berpartisipasi dalam kegiatan belajar untuk mencapai hasil pembelajaran yang maksimal sehingga peserta didik mampu menyerap pengetahuan serta mengubah tingkah lakunya menjadi lebih baik.

\footnotetext{
5 Sanjaya, Wina. Strategi Pembelajaran Berorientasi Standar Proses Pendidikan (Jakarta: Kencana Prenada Media, 2006), h. 124
} 
Ketika dunia pendidikan mengalami krisis yang cukup serius, konsep pendidikan telah berubah menjadi pengajaran, dan pengajaran lalu menyempit menjadi kegiatan di kelas. Sementara yang berlangsung di kelas tidak lebih dari kegiatan guru mengajar siswa supaya mendapat nilai yang memuaskan. Hal tersebut kurang memberikan tekanan terhadap pembentukan watak atau karakter, tetapi lebih pada hafalan dan pemahaman kognitif saja. Akibatnya ketika siswa masuk ke jenjang pendidikan yang lebih tinggi, mental akademik dan kemandirian belum terbentuk. Melihat kenyataan seperti itu, para pakar pendidikan harus memberi perhatian yang lebih besar khususnya pada sistem pengajaran.

Konfusius mengatakan: "yang saya dengar saya lupa, yang saya lihat saya ingat, dan yang saya kerjakan saya pahami”. Tiga pernyataan sederhana ini berbicara banyak tentang perlunya strategi belajar yang efektif. Dari tiga pernyataan tersebut, kemudian dimodifikasikan oleh Silberman menjadi paham belajar aktif, yaitu: "Yang saya dengar, saya lupa. Yang saya dengar dan lihat, saya sedikit ingat. Yang saya dengar, lihat, dan diskusikan dengan orang lain, saya mulai pahami. Dari yang saya dengar, lihat, bahas, dan terapkan, saya dapatkan pengetahuan dan keterampilan. Yang saya ajarkan kepada orang lain, saya kuasai”.

\section{MODEL STRATEGI BELAJAR AKTIF}

Beberapa model strategi belajar aktif yang dapat digunakan dalam proses belajar mengajar khususnya mata pelajaran pendidikan agama Islam, di antaranya adalah:

- Learning Jigsaw (Belajar Jigsaw) Learning Jigsaw merupakan teknik yang paling banyak dipraktekkan. Karena teknik ini serupa dengan pertukaran kelompok dengan kelompok, namun ada satu perbedaan yang penting dalam teknik ini, yaitu tiap siswa mengajarkan sesuatu. Tiap siswa mempelajari sesuatu yang berbeda dan bila digabungkan dengan materi yang dipelajari oleh siswa lain membentuk kumpulan pengetahuan atau keterampilan yang padu 6 .

- Problem Solving (Pemecahan Masalah)

Strategi pemecahan masalah adalah suatu strategi yang mendorong siswa mengawasi langkah-langkah yang mereka gunakan dalam memecahkan masalah. Mereka akan

\footnotetext{
${ }^{6}$ Hisyam. Strategi Pembelajaran Aktif, (Yogyakarta: Pustaka Insan Madani. 2008). h. xiv
} 
menunjukkan dan menjelaskan bagaimana mereka menyelesaikan masalah itu. Dengan menganalisis langkah-langkah yang rinci, guru dapat memperoleh informasi yang berharga tentang kecakapan pemecahan masalah yang dimiliki oleh siswa-siswa. Untuk menjadi pemecahan masalah, siswa perlu belajar berbuat dari pada hanya mengoreksi jawaban- jawaban masalah yang ada dalam buku teks.

- Snowballing

Snowballing adalah strategi memberdayakan siswa dengan membagi pertanyaan atau permasalahan yang berbeda-beda kepada kelompok kecil. Setiap anggota kelompok berkewajiban merumuskan jawaban atau pemecahan masalah sebagai bekal jika bergabung pada pembentukan kelompok baru. Karena setiap anggota kelompok yang baru berkewajiban berbagi jawaban atau pemecahan masalah dari kelompok sebelumnya.

- Card Sort

Card sort merupakan kegiatan kolaborasi yang bisa digunakan untuk bentuk mengajar konsep, penggolongan sifat, fakta tentang suatu obyek, atau mengulangi informasi. Gerakan fisik yang diutamakan dapat membantu untuk memberi energi kepada kelas yang telah letih.

\section{PRESTASI BELAJAR}

Belajar adalah suatu proses usaha yang dilakukan seseorang untuk memperoleh suatu perubahan dalam bentuk tingkah laku yang baru secara keseluruhan, sebagai hasil pengalamannya sendiri dalam interaksi dengan lingkungannya yang diwujudkan dalam bentuk kemampuan, kecakapan, pengetahuan, pemahaman, sikap, keterampilan, serta kebiasaan ${ }^{7}$.

Prestasi belajar merupakan hal yang tidak dapat dipisahkan dari kegiatan belajar, karena kegiatan belajar merupakan proses, sedangkan prestasi merupakan hasil dari proses belajar. Memahami pengertian prestasi belajar secara garis besar harus bertitik tolak kepada pengertian belajar itu sendiri. Adapun prestasi belajar juga dapat diartikan sebagai hasil dari suatu kegiatan yang diperoleh seorang siswa karena adanya aktivitas belajar yang telah dilakukan di suatu lembaga pendidikan pada umumnya.

\footnotetext{
${ }^{7}$ Slameto. Belajar dan Faktor yang Mempengaruhinya (Jakarta: Bina Aksara, 1988), h. 2
} 
Secara etimologi kata prestasi berasal dari bahasa Nedherland (Belanda) prestatie, kemudian diadopsi ke dalam bahasa Indonesia menjadi "prestasi" yang mengandung arti hasil dari suatu usaha ${ }^{8}$. Prestasi belajar merupakan penilaian pendidikan bagi perkembangan kemajuan siswa yang berkaitan dengan penguasaan bahan pelajaran yang disajikan kepada mereka serta nilai-nilai yang terdapat dalam kurikulum.

Sedangkan menurut terminologi Prestasi belajar adalah suatu bukti keberhasilan belajar atau kemampuan seorang siswa dalam melakukan kegiatan belajar sesuai dengan bobot yang telah dicapainya. Prestasi belajar dikatakan sempurna apabila afektif, dan psikomotorik, sebaliknya dikatakan prestasi kurang memuaskan jika seseorang belum mampu memenuhi target dalam ketiga kriteria tersebut.

Berdasarkan pengertian di atas, maka dapat diambil kesimpulan bahwa prestasi belajar merupakan tingkat kemampuan dasar yang dimiliki siswa dalam menerima, menolak dan menilai informasi- informasi yang diperoleh dalam proses belajar mengajar. Prestasi belajar seseorang sesuai dengan tingkat keberhasilan sesuatu dalam mempelajari materi pelajaran yang dinyatakan dalam bentuk nilai atau raport setiap bidang studi setelah mengalami proses belajar mengajar.

\section{FAKTOR-FAKTOR YANG MEMPENGARUHI PRESTASI BELAJAR}

Belajar selalu berkaitan dengan aktivitas yang menghasilkan perubahanperubahan pada diri individu yang melakukan belajar baik direncanakan maupun tidak. Hal lain yang juga selalu berkaitan dengan belajar adalah pengalaman, yaitu pengalaman yang berupa interaksi dengan orang lain maupun dengan lingkungannya. Unsur perubahan dan pengalaman tersebut berupa pengetahuan, kecakapan, keterampilan, sikap dan kebiasaan 9 .

Untuk mencapai prestasi belajar siswa sebagaimana yang diharapkan, maka perlu diperhatikan beberapa faktor yang dapat mempengaruhi prestasi belajar siswa antara lain; faktor internal (barasal dari diri siswa) dan faktor eksternal (berasal dari luar siswa). Adapun yang termasuk faktor internal adalah sebagai berikut:

- Faktor internal

\footnotetext{
${ }^{8}$ Aifin, Zainal. Evaluasi Intstruksional (Prinsip-Teknik-Prosedur), (Bandung: PT Remaja Rosdakarya, 1991), h. 2

${ }^{9}$ Sukmadinata, Nana. Landasan Psikologi pendidikan (Bandung: Remaja Rosdakarya, 2004), h. 155
} 
Faktor internal merupakan faktor yang berasal dari dalam diri siswa itu sendiri. Faktor ini terdiri dari faktor biologis dan psikologis ${ }^{10}$

- Faktor biologis

Faktor ini meliputi segala hal yang berhubungan dengan keadaan fisik individu siswa dan hal ini yang perlu diperhatikan oleh seorang guru yang bersangkutan. Kondisi fisik yang sehat dapat mempengaruhi motivasi belajar siswa dalam mengikuti pelajaran. Sementara kondisi fisik yang lemah dapat menurunkan kualitas belajarnya.

- Faktor psikologis

Faktor psikologis terdiri dari segala aspek yang berkaitan dengan kondisi mental siswa. Faktor ini sangat mempengaruhi tingkat keberhasilan belajar siswa.Adapun yang termasuk faktor psikologis adalah sebagai berikut:

- Intelegensi siswa

Intelegensi merupakan kemampuan belajar yang disertai dengan kecakapan untuk menyesuaikan diri dengan keadaan yang sedang dihadapinya. Intelegensi juga dapat diartikan tingkat kecerdasan seseorang dalam menghayati, memahami, serta menginterpretasikan mata pelajaran yang diterimanya dari seorang guru. Kecerdasan merupakan salah satu aspek yang penting dan sangat menentukan berhasil tidaknya studi seseorang. Semakin tinggi kemampuan intelegensi seorang siswa maka semakin besar peluangnya untuk meraih prestasi yang lebih tinggi.

- Bakat

Bakat adalah potensi (pembawaan) atau kemampuan tertentu yang telah dimiliki seseorang sebagai kecakapan. Bakat dalam hal ini lebih dekat pengertiannya dengan kata aptitude yang berarti bakat atau kecakapan. Tumbuhnya keahlian tertentu pada seseorang sangat ditentukan oleh bakat yang dimilikinya. Dalam proses belajar terutama belajar keterampilan, bakat memegang peranan yang penting dalam mencapai suatu prestasi yang baik. Bakat ini dapat mempengaruhi tinggi rendahnya prestasi belajar siswa.

- Minat siswa

Minat belajar yang telah dimiliki siswa merupakan salah satu faktor yang dapat mempengaruhi hasil belajarnya. Apabila seseorang mempunyai minat yang tinggi

${ }^{10}$ Syah, Muhibbin. Psikologi Pendidikan (Bandung: Remaja Rosdakarya, 1995), h. 133 
terhadap sesuatu hal maka akan terus berusaha untuk melakukannya sehingga apa yang diinginkannya dapat tercapai sesuai dengan keinginannya. Seseorang tidak akan melakukan sesuatu dengan baik tanpa adanya minat untuk melakukannya.

\section{- Motivasi}

Motivasi dalam belajar adalah faktor yang penting karena hal tersebut merupakan keadaan yang mendorong minat siswa untuk melakukan belajar. Motivasi adalah segala daya yang mendorong atau menggerakkan seseorang untuk melakukan sesuatu. Dalam motivasi terkandung dorongan mental yang dapat menumbuhkan keinginan serta perilaku individu untuk belajar ${ }^{11}$

- Faktor eksternal

Faktor eksternal adalah faktor yang berasal dari luar yang dapat mempengaruhi prestasi belajar siswa, yaitu beberapa pengalaman, keadaan keluarga, lingkungan masyarakat sekitarnya dan lain sebagainya. Pengaruh lingkungan ini pada umumnya bersifat positif dan tidak memberikan paksaan kepada individu. Faktor eksternal yang dapat mempengaruhi belajar siswa adalah sebagai berikut:

- Lingkungan keluarga

Keluarga merupakan lingkungan terkecil dalam masyarakat tempat individu dilahirkan dan dibesarkan. Keluarga merupakan lingkungan pendidikan yang pertama memberikan pengaruh pada seorang anak, karena dalam keluarga ini seorang anak pertama kali mendapatkan pendidikan dan bimbingan. Tugas utama keluarga bagi pendidikan anak ialah sebagai peletak dasar bagi pendidikan akhlak dan pandangan hidup keagamaan.

- Lingkungan sekolah

Sekolah merupakan lembaga pendidikan formal pertama yang sangat penting dalam menentukan keberhasilan belajar siswa. Sekolah adalah tempat dimana berlangsungnya proses belajar mengajar. Faktor sekolah yang mempengaruhi proses belajar siswa antara lain; metode mengajar guru, hubungan siswa dengan guru, hubungan siswa dengan siswa, alat-alat pelajaran dan kurikulum, keadaan sarana dan prasarana.

- Lingkungan masyarakat

\footnotetext{
${ }^{11}$ Dimyati. Belajar dan Pembelajaran (Jakarta: Rineka Cipta, 1999), h. 42
} 
Di samping orang tua, lingkungan juga merupakan salah satu faktor yang dapat mempengaruhi terhadap hasil belajar siswa dalam proses pembelajaran. Karena lingkungan alam sekitar sangat besar pengaruhnya terhadap perkembangan pribadi anak, sebab dalam kehidupan sehari-hari anak akan lebih banyak bergaul dengan lingkungan dimana anak itu berada.

Masyarakat terdiri atas sekelompok manusia yang menempati daerah tertentu, menunjukkan integrasi berdasarkan pengalaman bersama berupa kebudayaan, memiliki sejumlah lembaga yang melayani kepentingan bersama, mempunyai kesadaran akan kesatuan tempat tinggal dan bila perlu dapat bertindak bersama ${ }^{12}$.

\section{KESIMPULAN}

Berdasarkan uraian secara keseluruhan tentang hal-hal yang berkaitan dengan penerapan strategi pembelajaran aktif serta tahapan-tahapan pengelolaan dan analisis data, maka dapat ditarik kesimpulan sebagi berikut:

1. Penerapan strategi pembelajaran aktif sangat membantu dalam meningkatkan prestasi belajar pendidikan agama Islam. Karena penerapan strategi pembelajaran aktif sudah berjalan dengan baik. Salah satu bentuk penerapan strategi pembelajaran aktif adalah para guru pendidikan agama Islam memakai metode yang bervariasi yang terdiri dari metode ceramah, tanya jawab, diskusi, jigsaw leaning, hafalan, demonstrasi, resitasi, kerja kelompok, problem solving, latihan, dan tugas individu. Dalam penerapan metode-metode tersebut guru menyesuaikan dengan situasi dan kondisi psikologi siswa serta materi pembelajaran yang akan di sampaikan.

2. Penerapan strategi pembelajaran aktif menunjukkan hasil yang positif, hal ini dapat dilihat dari laporan hasil belajar siswa yang secara keseluruhan dapat memenuhi kriteria ketuntasan minimal yang telah ditetapkan oleh lembaga.

\section{DAFTAR PUSTAKA}

Aifin, Zainal. Evaluasi Intstruksional (Prinsip-Teknik-Prosedur), (Bandung: PT Remaja Rosdakarya, 99)

Dimyati. Belajar dan Pembelajaran (Jakarta: Rineka Cipta, 999)

\footnotetext{
${ }^{12}$ Nasution, Sosiologi Pendidikan (Jakarta: Bumi Aksara, 2004), h. 150
} 
Indrakusuma, Amir. Pengantar Ilmu Pendidikan Sebuah Tinjauan Filosifis (Surabaya: PT Usaha Nasional, 973)

Marimba, Ahmad. Filsafat Pendidikan Islam, (Bandung: PT. Al-Ma'arif, 984)

Sanjaya, Wina. Strategi Pembelajaran Berorientasi Standar Proses Pendidikan (Jakarta: Kencana Prenada Media, 2006)

Hisyam. Strategi Pembelajaran Aktif, (Yogyakarta: Pustaka Insan Madani. 2008).

Slameto. Belajar dan Faktor yang Mempengaruhinya (Jakarta: Bina Aksara, 988)

Sukmadinata, Nana. Landasan Psikologi pendidikan (Bandung: Remaja Rosdakarya, 2004)

Syah, Muhibbin. Psikologi Pendidikan (Bandung: Remaja Rosdakarya, 995)

S. Nasution, Sosiologi Pendidikan (Jakarta: Bumi Aksara, 2004)

Tim Penyusun Kamus Pusat Pembinaan dan Pengembangan Bahasa, Kamus Besar Bahasa Indonesia (Jakarta: Balai Pustaka, 990)

Undang-Undang Sistem Pendidikan Nasional No. 20 Tentang Sistem Pendidikan Nasional (Bandung: Penerbit Citra Umbara, 2003) 